\title{
クリオプレシピテートおよびフィブリノゲン製剤の使用実態について
}

山本 晃士 前田 平生

キーワード : 大量出血, 凝固障害, クリオプレシピテート, フィブリノゲン製剂

本誌 61 巻 6 号に揭載された原著にて菅野らは, 2014 年度の血液製郕使用実態調查をもとに「大量出血にお ける FFP, クリオおよびフィブリノゲン製剤の使用状 況」を報告している ${ }^{1)}$.しかし本アンケート結果 ${ }^{233}$ 抒よ び 2013 年度の大量輸血症例の検討)を見ても，回答施 設数の少なさから，両製剂の使用実態は明確になって いない. 大量出血時の凝固障害に対してクリオプレシ ピテートおよびフィブリノゲン製剂を使用したと回答 した施設数を見ると, 基本調査2 ではそれぞれ 44(4.8\%), $124(14.2 \%)$ だが，詳細調查３）では同 22，55(両製剤使 用は15）と半減して扮り，ささらに個別報告にいたって は同 13，12（両製郕使用は 2）と，きわめて限られた 施設からの回答のみとなっている。これでは両製剤の 使用実態を把握することは難しいと言わざるを得ず, 本アンケートの限界でもある。 ちなみに，さらなる問 い合わせを可とした施設数は, クリオプレシピテート 使用 22 施設のうち 11 ，フィブリノゲン製郕使用 55 施設のうち 14 , 両製剂使用 15 施設のうち 8 にとどまっ ていた。

これまで我が国では，供給体制の不備掞よび保険適 用外での使用という事情から，両製剤の普及が遅れて いた。また，その使用にあたっては統一した使用基準 を設けておくことが推奨されるが, 実際には施設によっ て運用がまちまちであり，両製凨の有効性を客観的に 評価する上でも大きな妨げとなっている，両製郕が必 要とされる病態も一様ではなく, 各分野の専門医の間 で使用の是非や使用基準について意見が分かれている. 本アンケートの個別症例報告から算出した両製剂の使 用診療科割合を見ると, クリオプレシピテート（167 例) は心臟血管外科が 4 分の 3 を占めているのに対し, フィブリノゲン製剤 (103 例) は産科や救命救急領域で の使用割合が高い傾向を示している（図 1)。この違い の理由は明らかではないが，おそらく心臟血管外科手 術件数の多い施設では，主科からの要望によりクリオ
プレシピテートを導入したのではないかと推測される. 一方, 産科大量出血や救命救急領域では凝固障害がよ り高度で緊急性も高いことが多く, 救命のために必要 な，濃縮されたフィブリノゲンの迅速投与を行いやす いフィブリノゲン製剤のほうを使用する傾向にあるの かもしれない.日本血液製剤機構によると，2015 年の フィブリノゲン製片の年間使用量は約 $8,000 \mathrm{~g}$ で，その うち約 $3,000 \mathrm{~g}$ が先天性欠乏症患者に使用されていると いう.つまり約 $5,000 \mathrm{~g}$ が後天的な低フィブリノゲン血 症患者に投与されていると推測され，1例あたり $3 \sim 4$ $\mathrm{g}$ の投与と考えると, 年間 $1,200 \sim 1,500$ 例の症例で使用 されていることになる.

このように本アンケートには，両製剂の使用状況の ごく一部が反映されているに過ざない，次年度以降の アンケート調查内容を改変することにより，また本学 会の「クリオ・フィブリノゲン製剤小委員会」での活 動により，両製剤の使用実態がより明らかにされ，適 正な使用指針の作成に寄与することを期待する.

著者の COI 開示：本論文発表内容に関連して特に申告なし

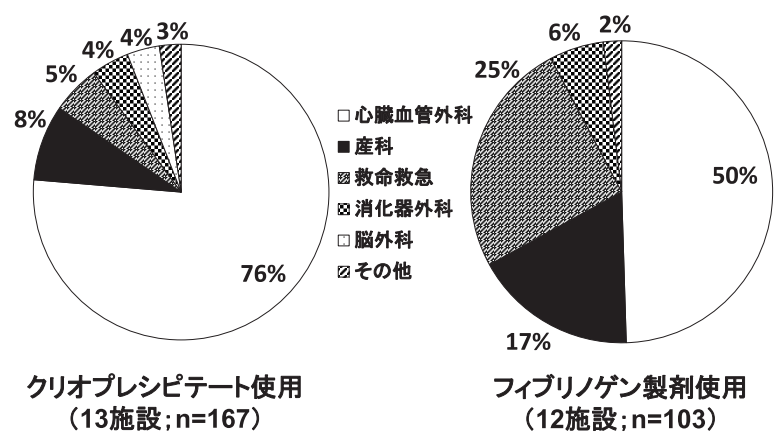

図 1 クリオプレシピテートおよびフィブリノゲン製剤の使 用診療科別割合 (平成 26 年全国アンケート調查結果より) 
文献

1）菅野 仁, 牧野茂義, 北澤淳一, 他：2014 年度 日本に おける輸血管理体制と血液製剂使用実態調査報告. 日本 輸血細胞治療学会誌, $61: 529-538,2015$.

2) https://www.jstmct.or.jp/Questionnaire/Report/201 4/Basic.pdf
3) https://www.jstmct.or.jp/Questionnaire/Report/201 4/Detail.pdf

4）前田平生, 阿南昌弘, 田中朝志, 他：本邦における大量 輸血症例の検討一平成 25 年血液製剂使用実態詳細調査 (300 床以上) 上り一. 日本輸血細胞治療学会誌, $61: 409-$ $418,2015$.

\section{CURRENT SITUATION ON THE USE OF CRYOPRECIPITATE OR FIBRINOGEN CONCENTRATE IN JAPAN}

\section{Koji Yamamoto and Hiroo Maeda}

Department of Transfusion Medicine and Cell Therapy, Saitama Medical Center, Saitama Medical University

\section{Keywords:}

massive hemorrhage, coagulopathy, cryoprecipitate, fibrinogen concentrate

(C)2016 The Japan Society of Transfusion Medicine and Cell Therapy

Journal Web Site: http://yuketsu.jstmct.or.jp/ 